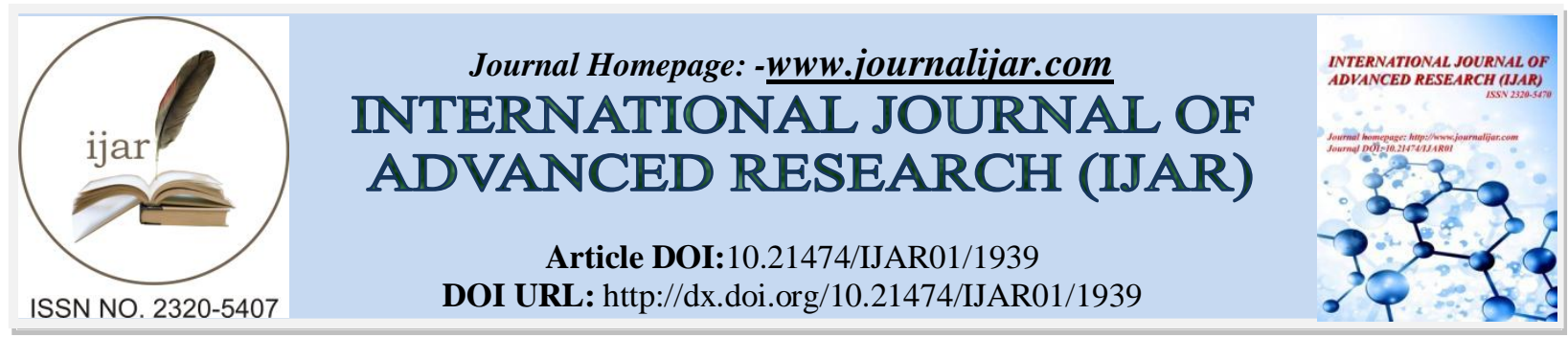

RESEARCH ARTICLE

\title{
DETERMINATION OF SELENIUM IN WHOLE BLOOD OF CARDIOVASCULAR DISEASE PATIENTS IN BASRA CITY BY HYDRIDE GENERATION ATOMIC ABSORPTION SPECTROMETRY.
}

University of Basrah college of science chem Department.

\section{Manuscript Info}

Manuscript History

Received: 12 August 2016

Final Accepted: 22 September 2016

Published: October 2016

\section{Abstract}

A developed hydride generation atomic absorption method for the determination of selenium using a Micro reaction vessel of a volume $10 \mathrm{ml}$ and $13 \mathrm{~mm}$ in diameter for the analysis of small volumes of biological fluids such as whole blood and serum. The optimum conditions used for determination were $(1.5 \mathrm{M}$ $\mathrm{HCl}$ medium), $\mathrm{N}_{2}$ Flow $(2 \mathrm{~L} / \mathrm{min})$ reducing agent $(2 \% \mathrm{w} / \mathrm{v}$ $\mathrm{NaBH}_{4}$ ).It has been found that the detection limitof the method $(1.36 \mathrm{ng} / \mathrm{ml})$, sensitivity $(0.045 \mathrm{ng} / \mathrm{ml})$, linear $(0.0-200 \mathrm{ng})$ with recovery (82.7-106)\%for whole blood sample. The results reveals that low selenium contents of the whole blood of male patients $(40,84 \mathrm{ng} / \mathrm{ml})$ and $33.33 \mathrm{ng} / \mathrm{ml}$ for female patients as compared with healthy whole blood $(95.34 \mathrm{ng} / \mathrm{ml})$ For male and $(82.0 \mathrm{ng} / \mathrm{ml})$ for female respectively.

Copy Right, IJAR, 2016,. All rights reserved.

\section{Introduction:-}

Selenium is an essential trace element and an important constituent of some endogenous enzyme glutathione peroxidase which represent an extremely effective protective System for insufficient ${ }^{(1)}$ activity of enzyme can be the reason for metabolic disturbance of the body cells and serves as a radical scavenger. It has been found that peroxy radicals Play a decisive role in inflammatory, degenerative and chronic illnesses. Because of its antioxidant properties, it has long been hypothesized that selenium may prevent cardiovascular and other chronic diseases. There are an association between a lower antioxidant intake with greater incidence of heart diseases A additional lines of evidence suggest that oxidative stress from free radicals may promote heart diseases ${ }^{(2)}$ In this research developed direct method for the determinations of Se in whole blood has been used, the method was found to be rapid accurate and sensitive.

\section{Reagents:-}

$1000 \mathrm{ppm}$ selenium solution was prepared from selenium dioxide $1 \% \mathrm{~W} / \mathrm{V}$ sodium borohydride solution was prepared by dissolving $1 \mathrm{~g}$ of sodium borohydride in $100 \mathrm{~mL}$ of the deionized water it was freshly prepared . $1.5 \mathrm{M}$ $\mathrm{HCl}$ solution was prepared by diluting $147.3 \mathrm{~mL}$ of. concentrated $(2 \mathrm{M}) \mathrm{HCl}(1 \mathrm{M}) \mathrm{HNO} 3$ solution was prepared by taking $6.8 \mathrm{~mL}$ from the concentrated solution and diluted to $50 \mathrm{~mL}$ by deionized water (1:1) HCl and $\mathrm{HNO} 3$ Acid solution was prepared by taking one volume of each and diluted with one volume distilled water 


\section{Instruments:-}

The shimadzo atomic absorption spectrometry model AA 630-12 was used for the analysis and a home-made hydride generation kit also used as shown in figure(1)

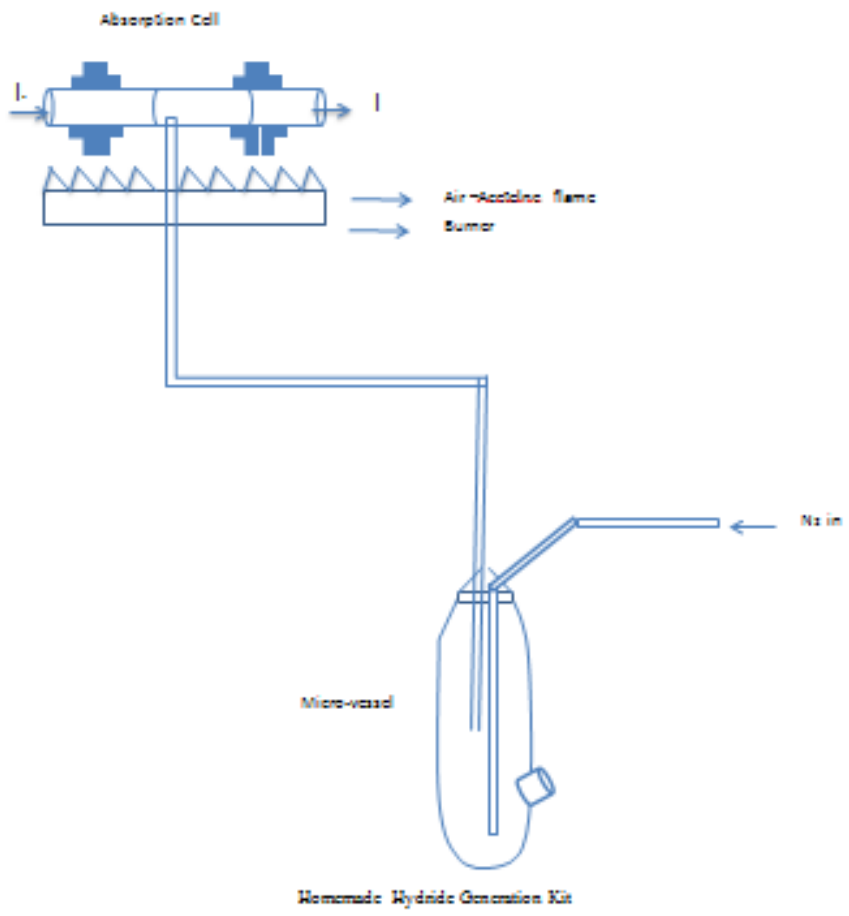

\section{General procedure:-}

Figure 1:- Home made hydride generation kit

40ng of selenium were placed in a reaction vessel by taking $0.2 \mathrm{~mL}$ of(200 $\mathrm{ng}$ per ml) selenium solution Then 0.2 $\mathrm{mL}$ of $(2 \% \mathrm{~W} / \mathrm{V})$ sodium borohydride solution was added to the reaction vessel the content were mixed well by shaking and Selenium were liberated hydride was pushed by nitrogen gas with rate of $3 \mathrm{~L} / \mathrm{min}$ to the reaction cell and atomic absorption signal of selenium was measured using 196.1 nanometer wavelength The effect of other factors such as flow rate of nitrogen gas, volume and concentration of reductant different heating time of absorption cell different selenium concentration and different volume of selenium all these factors were optimized as shown in figure $1,2,3,4$ and 5 


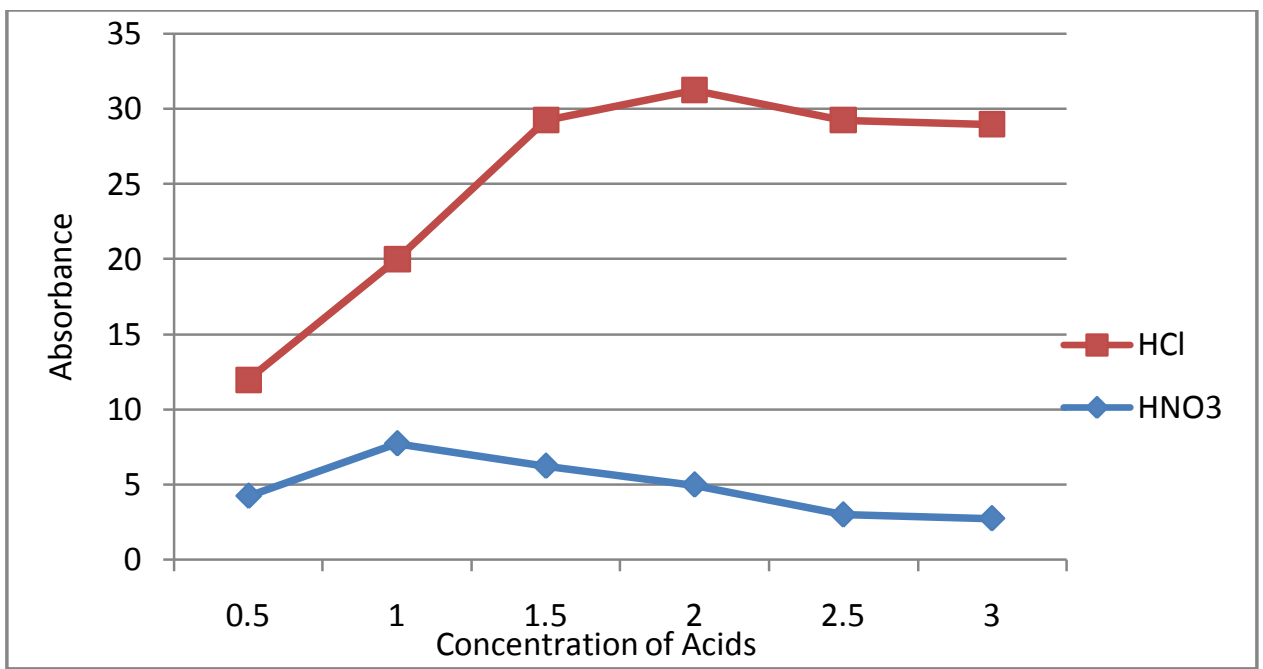

Figure 2:- Effect of acids on the absorbance of 40ng Se.

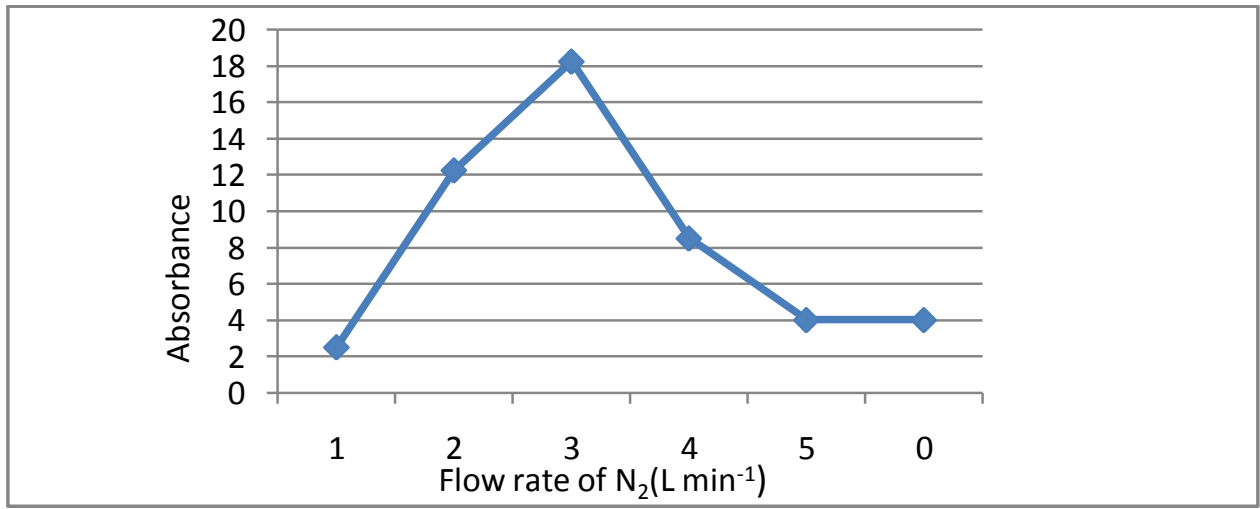

Figure3:- Effect of different flow rate of $\mathrm{N}_{2}$ on the absorbance of 40ng Se

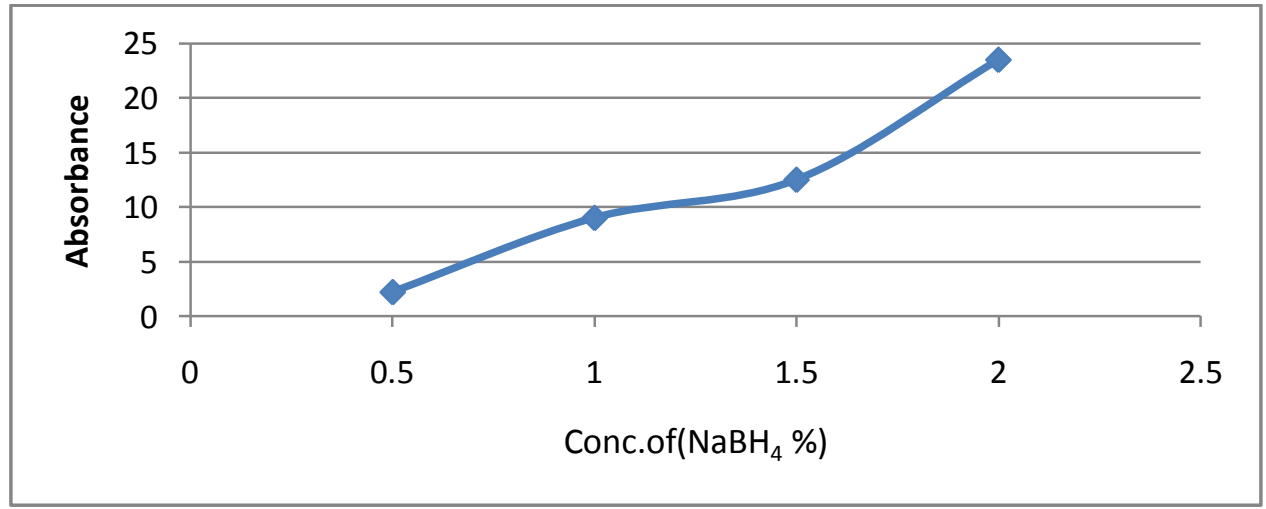

Figure 4:- Effect of different Conc of $\mathrm{NaBH}_{4}$ on the absorbance of 40ng Se. 


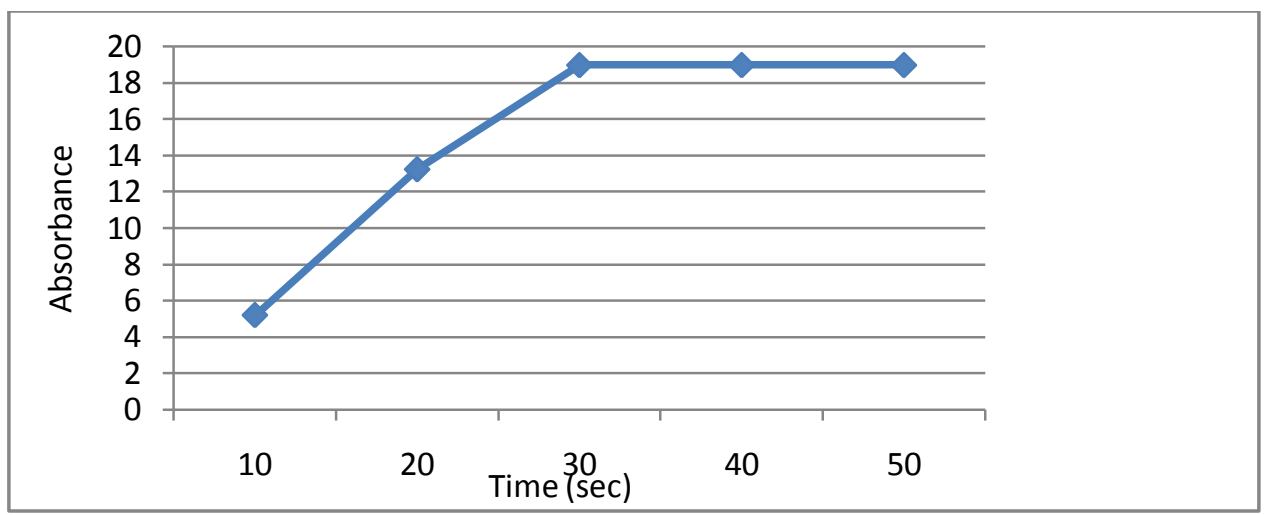

Figure 5:- Effect of heating time of absorption cell on the absorbance of 40ng Se

\section{Sample collection:-}

Blood samples were collected from 178 cardiovascular patients and healthy control person these samples were related to different life spans and different gender and the local of collection was basra hospital and some health centers trees the blood sample was kept in polyethylene vials containing potassium ethylene diamine tetra acetic acid as coagulant and stored in a refrigerator at $-20^{\circ} \mathrm{C}$ till analysis

\section{Sample digestion:-}

$0.5 \mathrm{~mL}$ of blood sample $2 \mathrm{~mL}$ concentrated $\mathrm{HNO}_{3}$ were added to it then solution was butted in a water path (100$\left.110^{\circ} \mathrm{C}\right)$ till complete dissolution and the solution become clear(2-3hrs) this solution was diluted with $1.5 \mathrm{M} \mathrm{HCl}$ to 5 $\mathrm{mL}$ Then heated in a water bath at $\left(60-70^{\circ} \mathrm{C}\right)$ for $(20-30)$ minutes to convert all selenium 6 to Se four Then the sample were cooled then diluted to $5 \mathrm{~mL}$ with $1.5 \mathrm{M} \mathrm{HCl}$.

Table 1:- Optimization conditions for the determination of Se using NaBH4 as reductant.

\begin{tabular}{|l|l|}
\hline Optimum Conditions & Parameters \\
\hline $1.5 \mathrm{M}$ & $\mathrm{HCl}$ concentration \\
\hline $30 \mathrm{Sec} \geq$ & Heating time \\
\hline $2 \%$ & Concentration time \\
\hline $0.2 \mathrm{ml}$ & Volume of $\mathrm{NaBH}_{4}$ \\
\hline $3 \mathrm{~L} \mathrm{Min}$ & N2 Flow rate \\
\hline $0.2 \mathrm{ml}^{-1}$ & Volume of standard solution \\
\hline
\end{tabular}

Construction of selenium calibration graphs:-

$0.2 \mathrm{~mL}$ of selenium solution was injected into a reaction vessel followed by adding $0.2 \mathrm{~mL}$ of $2 \% \mathrm{~W} / \mathrm{V}$ sodium borohydride solution using micropipette. The content of the vessel was stirring well and the nitrogen gas with the flow rate of $3 \mathrm{~L} / \mathrm{min}$ was used for pushing the liberated selenium hydrides to the absorption cell and the atomic absorption signal of selenium was measured using $191.1 \mathrm{~nm}$.

\section{Results and Discussion:-}

Optimization conditions for selenium determination:-

The atomic absorption signal of $40 \mathrm{ng}$ selenium was measured using different acid media the results revealed that the use of $\mathrm{HCl}$ as acidic medium for the hydride generation gives higher atomic absorption signal than $\mathrm{HNO} 3$ acidic media figure.

Effect of different nitrogen flow rates the atomic absorption signal of selenium was affected by the purity of nitrogen ,impure nitrogen with purity less than $99 \%$ gives a background absorption which cover Se signal and then none reproducible signal were obtained therefore high purity of nitrogen $99.999 \%$ should be used and different flow rate used to force $\mathrm{SeH} 2$ to the absorption cell as shown in fig2 which reveals that $3 \mathrm{~L} / \mathrm{min}$. was the best rate. 


\section{Effect of sodium borohydride concentrations:-}

Figure 3 shows the effect of different concentration of sodium borohydride on the AA signal.of selenium, it's clear that the concentration of $(2 \% \mathrm{~W} / \mathrm{V})$ sodium borohydride are sufficient to reduce the selenium +4 ions to $\mathrm{SeH}_{2}$ and give the higher signal of Se.

\section{The effect of different time of absorption cell:-}

using different time for the heating of absorption cell gives different absorption signal for Selenium as shown in figure 4 the low temperature of heating using less time gives less signals and as the time of hearing increases the signal of selenium was increases it reaches maximum at 30 seconds of heating time fig. 4

\section{Calibration graph:-}

we can construct the calibration by using different volume of a certain standards ( $200 \mathrm{ng} / \mathrm{ml}$ ) se solution by taking different volumes of a standard solution to construct their calibration as shown in figure 5

\section{Optimization conditions:-}

The optimize conditions for the determination of selenium by hydride generation was shown in table 1 and under these conditions we can construct calibration graphs with a range $(0-200) \mathrm{ng} / \mathrm{ml}$ as shown in figure 6 .

\section{The analysis methods}

Two methods direct and standard addition are used for the determination of selenium in whole blood which indicated in table 2 and figure 8 and 9 The obtained results shows that a good compatibility between method and standard addition method. The accuracy of direct method was found to be(92-109)\%. and recovery percent of.(82.7106)\% the direct method.was reliable when compared our result with other studies $(6,7)$

Generally the results show a low selenium content of the whole blood of male patients $(40.84 \mathrm{ng} / \mathrm{ml})$ and $(33 \ldots$ $\mathrm{ng} / \mathrm{ml})$ for female as compared with healthy whole blood $(95.34 \mathrm{ng} / \mathrm{ml})$ for male and $(82.0 \mathrm{ng} / \mathrm{ml})$ for female respectively

Table 2:- Determination of selenium by direct method as compared with standard addition.

\begin{tabular}{|l|l|l|l|}
\hline $\begin{array}{l}\text { Accuracy } \\
\%\end{array}$ & $\begin{array}{l}\text { Conc. Of Se in whole Blood } \\
\text { (ng/ml) by Addition }\end{array}$ & $\begin{array}{l}\text { Conc. Of Se in whole } \\
\text { Blood (ng/ml) by direct }\end{array}$ & Sample \\
\hline 109 & 22 & 24 & $\mathrm{~A}$ \\
\hline 92.30 & 65 & 60 & $\mathrm{~B}$ \\
\hline 105 & 80 & 84 & $\mathrm{C}$ \\
\hline 97.36 & 76 & 74 & $\mathrm{D}$ \\
\hline 96.77 & 124 & 120 & $\mathrm{E}$ \\
\hline 100 & 18 & 18 & $\mathrm{G}$ \\
\hline 100 & 52 & 52 & $\mathrm{H}$ \\
\hline 100 & 88 & 88 & $\mathrm{I}$ \\
\hline 100 & 52 & 52 & $\mathrm{~J}$ \\
\hline 97.36 & 76 & 74 & $\mathrm{~K}$ \\
\hline 100 & 88 & 88 & $\mathrm{~L}$ \\
\hline
\end{tabular}




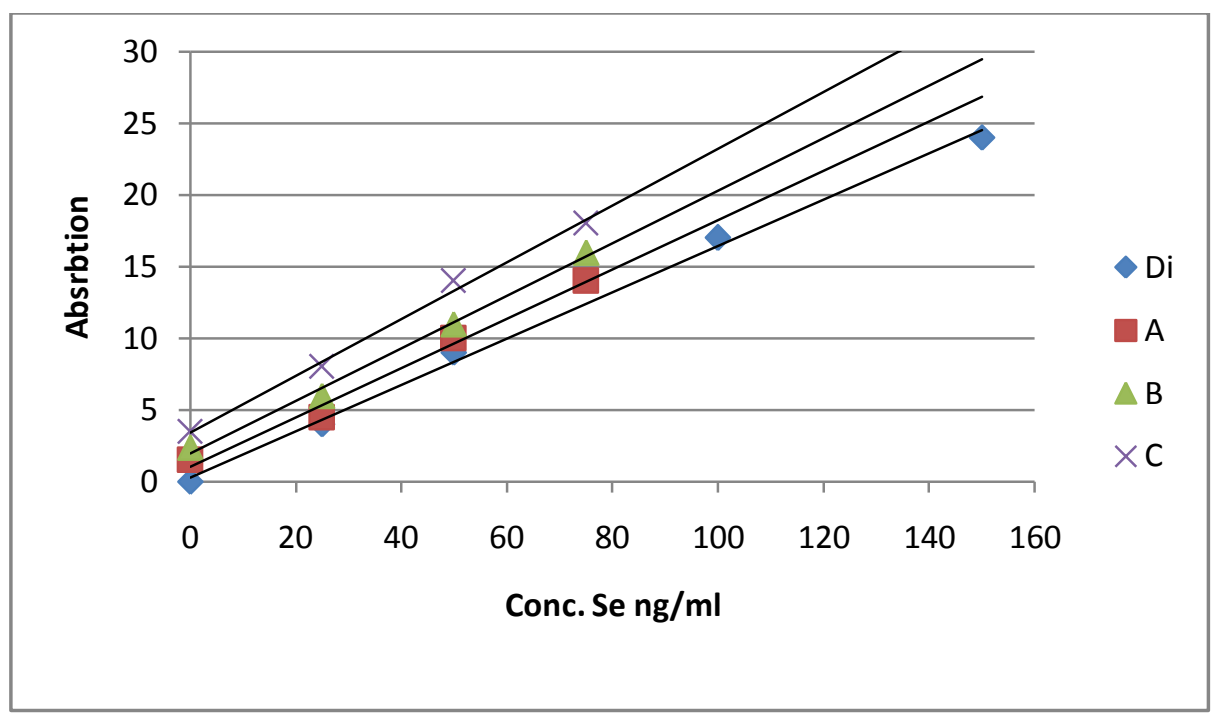

Figure 7:- Determination of Selenium in whole Blood by Direct Method and standard addition method

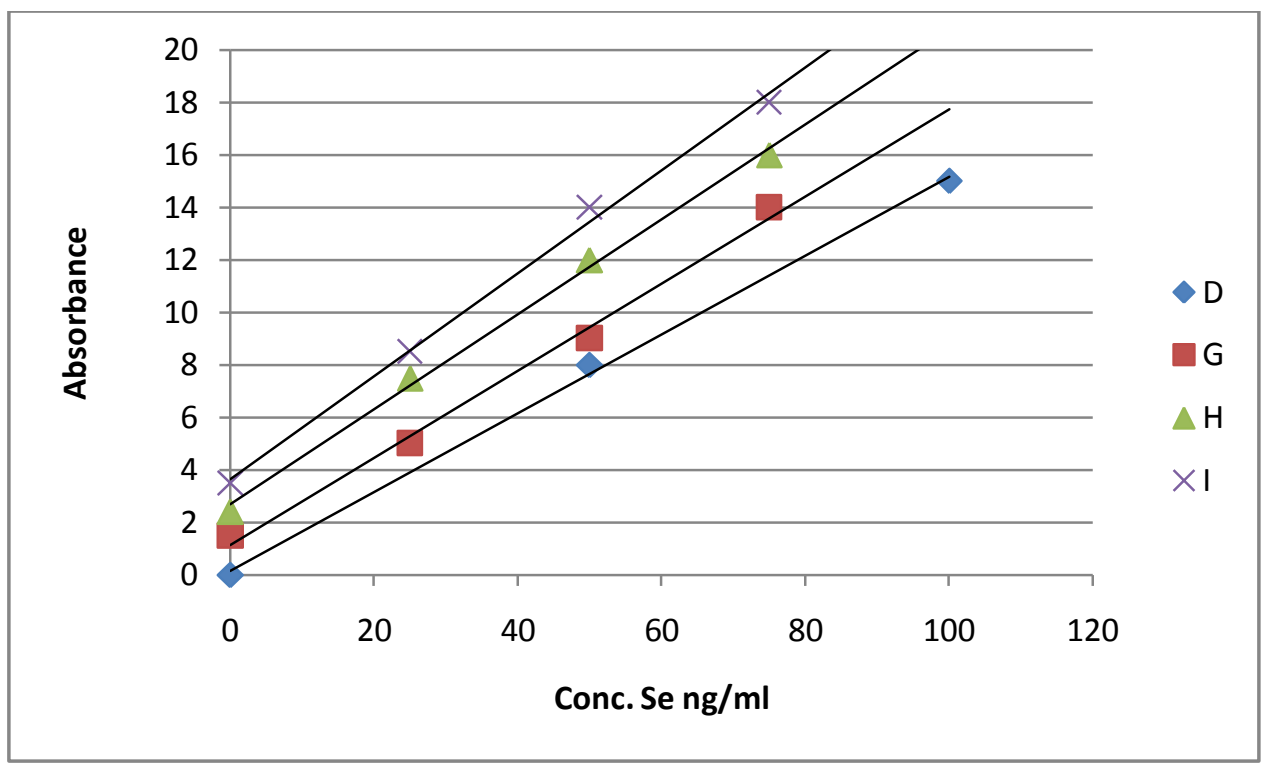

Figure 8:- Determination of Selenium in whole Blood by Direct Method and standard addition method

\section{Reference:-}

1. $\quad$ S jA, King IB ,Morris JS, Stratton K, White E. Toenail and plasma levels as biomarkers of selenium exposure. Ann Epidemiol 2005:16:53-8

2. GeyKF.y Vitamin E plus $C$ and interacting constraint required for optimal Health. A Critical and constructive review of epidemiology and supplementation data regarding cardiovascular disease and cancer, Biofactors 1998:7:113-74

3. Lapenna P, de Gioia S, ciofani G, Mezzetti A. ,ucchino S, calafiore AM, -Napolitano AMDillo C. , Cuccurullo F. , "glutathione - related antioxidant defenses in Human Atherosclerotic plaques . circulation 1998,97,1930-4

4. Ozer NK, Boscoboinik D, Azzi A, New roles of low density lipoprotein and Vit..E In the pathogenesis of atherosclerosis.Biochem Mol.Biol.Int.1995;35:117-

5. Neve J. selenium as a risk factor for cardiovascular disease J- cardiovascular Risk 1996,3,42-47

6. Hussain T. Abdul Sahib Analytical Study for determination of selenium in Human teeth by hydride generation atomic absorption Spectrometry ,Basrah university, college of science. them deportment 1999

7. Gemma.F.M,and N.A, Roberto P.B. and Elisa"Selenium and coronary heart disease:a metaanalysis"AmClin.Nutr. , 2006;84,762-773. 